\title{
Correction to: miR-484 suppresses proliferation and epithelial-mesenchymal transition by targeting ZEB1 and SMAD2 in cervical cancer cells
}

Yang Hu, Hong Xie, Yankun Liu, Weiying Liu, Min Liu and Hua Tang*

\section{Correction to: Cancer Cell Int (2017) 17:36}

https://doi.org/10.1186/s12935-017-0407-9

Following publication of the original article [1], the authors notified us the transwell invasion image for ASO$\mathrm{NC}$ of HeLa cell in Fig. 3b was wrongly placed by mistake during the preparation of the figure. The corrected version of Fig. $3 \mathrm{~b}$ is provided below (in the red box). This correction does not change the conclusions of this paper.

\section{Reference}

1. Hu Y, Xie H, LU , ang H. miR-484 suppresses proliferation and epithelial-mes hymal transition by targeting ZEB1 and SMAD2 in cervical ancer cells. o cer Cell Int. 2017;17:36. https://doi.org/10.1186/ s12935-C

\section{Puhlisher's yote}

Spm. Nature remains neutral with regard to jurisdictional claims in published, ps and institutional affiliations.

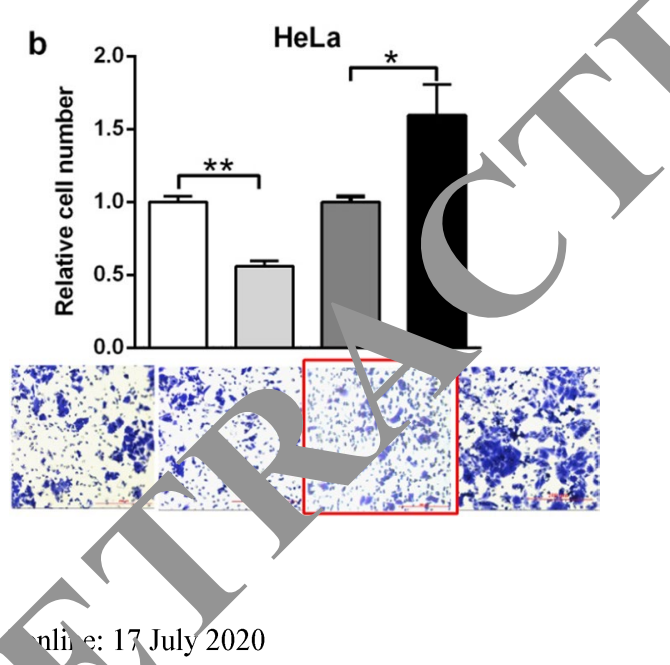

Publishe nli e: 17 July 2020

The on lal artic an be found online at https://doi.org/10.1186/s1293

${ }^{*} \mathrm{Co}$ ondence: tangh@tijmu.edu.cn

Tianjin, e Science Research Center and Department of Pathogen Biology, School of Basic Medical Sciences, Tianjin Medical University, 22

Qi-Xiang-Tai Road, Tianjin 300070, China

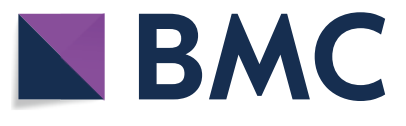

The This article is licensed under a Creative Commons Attribution 4.0 International License, which permits use, sharing, adaptation, distribution and reproduction in any medium or format, as long as you give appropriate credit to the original author(s) and the source, provide a link to the Creative Commons licence, and indicate if changes were made. The images or other third party material in this article are included in the article's Creative Commons licence, unless indicated otherwise in a credit line to the material. If material is not included in the article's Creative Commons licence and your intended use is not permitted by statutory regulation or exceeds the permitted use, you will need to obtain permission directly from the copyright holder. To view a copy of this licence, visit http://creativeco mmons.org/licenses/by/4.0/. The Creative Commons Public Domain Dedication waiver (http://creativecommons.org/publicdomain/ zero/1.0/) applies to the data made available in this article, unless otherwise stated in a credit line to the data. 